KEYWORDS

Innovations

Competition

Productivity

Science and technology

Human resources

Local development

Development policy

Argentina

Gabriel Yoguel

Teacher-researcher at the Institute

of Industry (IDEI),

General Sarmiento National

University,

Buenos Aires Province, Argentina

○ gyoguel@ungs.edu.ar

José A. Borello

Teacher-researcher at the

Conurbation Institute (ICO),

General Sarmiento National

University,

Buenos Aires Province, Argentina

- jborello@ungs.edu.ar

Analía Erbes

Teacher-researcher at the Institute of Industry (IDEI),

General Sarmiento National

University,

Buenos Aires Province, Argentina

œ aerbes@ungs.edu.ar
CEPAL REVIEW 99 - DECEMBER 2009

\section{Argentina: how to study and act upon local innovation systems}

\author{
Gabriel Yoguel, José A. Borello and Analia Erbes
}

$\mathrm{T}$

his article examines a number of ideas about local innovation systems, how best they can be studied and what needs to be done to develop them further. It is based on experiences in Latin America generally and Argentina in particular. The first part briefly reviews the literature on local production and innovation systems. Following this, 10 hypotheses about the workings of innovation systems are presented, together with the same number of approaches to studying the characteristics and potential of any specific existing system. The third part sets out a number of measures that could be applied to improve local innovation systems in a given country or region. This paper argues that it is both possible and necessary to build bridges between analysis and action, theory and practice. 


\section{I}

\section{Introduction}

The purpose of this article is to systematize a number of ideas about the workings of local innovation systems and the measures that could be taken to develop them further. We address a range of issues that are of central importance in any evaluation of the way these operate and in the design of policy actions to increase the capabilities and connectivity of systems of this type. Although most of the issues discussed derive from an analysis of the Argentinean experience, it is possible that they may also illustrate the situation of other Latin American countries.

Although studies of the subject have yielded an increasingly precise description and understanding of the 'local innovation system' concept, they have made less progress in identifying certain general characteristics. Again, while policies centred on what we might generically call local development have become increasingly important in Latin America, there has not been any major effort to stylize the different approaches and delineate possible areas of action. ${ }^{1}$ Nonetheless, some recent critical contributions do coincide, on certain points, with our approach (Fernández, Amín and Vigil, 2008).

This article is divided into six sections. Following this introduction, the second section gives a stylized description of the main contributions of the literature to the topic under discussion. The third part presents a conceptualization of local innovation systems and discusses a number of theories about how they operate, arising from research carried out in Argentina. The fourth section proposes a methodology for studying them. The fifth section lays out a number of policy measures that, in our view, ought to be implemented to improve the functioning of systems of this type. Lastly, we present our conclusions.

\section{II}

\section{The nature and importance of local innovation systems}

The importance of the issues discussed in this article can be appreciated from a number of facts reported in recent studies. These studies have argued that economic agents are operating within a framework of growing competition, that the nature of this competition has changed and that a higher level of cognitive capabilities is required (Ernst and Lundvall, 1997; Lall, 1992; Yoguel and Boscherini, 1996). It is also argued that these capabilities do not derive only from particular static factors, but that the institutional environment firms operate in has become more important. Part of this environment is constructed and replicated $\square$ This article is based on a document prepared for the project "Sistema nacional y sistemas locales de innovación Estrategias empresarias innovadoras y condicionantes meso y macroeconómicos" implemented by the National Science and Technology Observatory of the Science and Technology Secretariat (SECyT), under the coordination of Mario Albornoz (see [online] www.secyt.gov.ar). Earlier versions were presented at the following events: a seminar entitled "Conglomerados productivos: competitividad, desarrollo local e innovación", Special Programmes and Projects area, SECyT, October 2005; the eleventh Annual Meeting of the SME-MERCOSUR Network, Tandil, September 2006; the ninth Small and Medium-Sized Enterprise
Conference, Professional Council of Economic Sciences of the Autonomous City of Buenos Aires, November 2006; and in English ("Local innovation systems in Latin America: Theoretical, methodological and policy lessons for other regions of the South") at the fourth International Conference of the Global Network for the Economics of Learning, Innovation, and Competence Building Systems (GLOBELICS), Kerala, India, October 2006. The authors are grateful for the comments received at these events and for those of an anonymous CEPAL Review referee. José A. Borello is also a CONICET researcher.

1 The main exceptions are the studies by Albuquerque (2004), Boisier (2004) and Vásquez Barquero (2000). 
in geographical areas that are local and regional in nature (Albadalejo and Romijn, 2000; Camagni, 1991; Morgan, 1995; Nomisma, 1993; Poma, 2000).

Although the whole issue of local development is only now coming to prominence on the public agenda and in the policies applied by the governments of Latin America in recent years (Albuquerque, 2004), this is a subject that goes back a long way in disciplinary fields such as urban sociology, urban planning, geography and economics, so much so that Marshall (1890) himself discusses two central aspects of any local innovation system: the relationships between economic agents and their territorial expression.

Marshall's emphasis on the division of labour connects him with classical authors such as Smith, Marx and Durkheim (Groenewegen, 1987), as well as with contemporary ones. Thus, while Sayer and Walker (1992) consider the division of labour to be an important aspect in the analysis of different economic systems, Fröbel, Heinrichs and Kreye (1980) and Massey (1995) believe that, in its geographical variant particularly, it can yield an understanding of the production structure and the logic thereof. However, it was Scott (1988 and 1993) who made a more direct connection between the division of labour and the evolving characteristics and nature of local production and innovation systems.

Hirschman (1958), for his part, emphasized not the division of labour but the nature and meaning of relationships between firms. ${ }^{2}$ As he sees it, development requires the mobilization of hidden resources and the construction of a public space that is crucial for the formation of a democratic society where private interests do not dominate. Hirschmanian thinking gave rise to a number of later elaborations addressing, among other issues, the qualitative attributes of production systems (Fredriksson and Lindmark, 1979), unequal power relationships within these (Coraggio, 1987; Rofman, 1984; Taylor and Thrift, 1983) and their role in reducing uncertainties (Storper and Walker, 1989). Interest in these production clusters gave rise to a whole terminology around the issue: subcontracting networks (Holmes, 1986; Scott, 1983 and 1986), distribution networks (filières) (Truel,

\footnotetext{
${ }^{2}$ Hirschman's approach also explains the reasons for unbalanced development in Latin America, the emergence of economic groups, the tensions between exit and voice, the formation of progressive and regressive alliances and the weaknesses present in production chains.
}

1983), sectoral blocks (Lifschitz, 1986) and commodity chains (Hopkins and Wallerstein, 1986; Gereffi and Korzeniewicz, 1990).

When production systems came to be analysed from the territorial point of view, new concepts emerged such as territorial production complexes (Gorenstein, 1993; Smith, 1981; Storper and Walker, 1989), clusters (Humphrey and Schmitz, 2000) and territorial circuits of production, circulation and accumulation (Coraggio, 1987; Rofman, 1984). The term "industrial district", originally used by Marshall, was dusted off by Italian and then English-speaking authors to refer to the geographical concentration of closely interrelated firms for the purpose of producing certain goods (Piore and Sable, 1984). The industrial district idea was later applied to a variety of production systems (Markusen, 1995).

While much of the literature we have touched upon assumes that knowledge- and capacity-building and incorporation processes underlie the interaction of local systems, most of these studies do not articulate an explicit interest in these subjects. To some extent, this is because these processes have begun to receive a more precise characterization only in the past two decades.

Against this background, Marshall's industrial district idea was taken up by authors who emphasized that learning and innovation took place within spatially concentrated production systems. Thus, for example, it was noted that clusters generate spillovers and collective learning. Some authors understood the industrial district as a cognitive laboratory producing spillovers of knowledge related to the public good concept (Bellandi, 1989; Becattini, 1990). Other approaches highlighted the importance of the informal sharing of knowledge among economic agents as a source of competences $^{3}$ (Camagni, 1991; Capello, 1999; Maskell and Malmberg, 1999), while studies carried out in Silicon Valley and Denmark, Sweden and Norway (Saxenian, 1996; Dahl, 2002; Power and Lundmark, 2004; Stambol, 2003) have shown that the spread of knowledge resulting from worker mobility within a local system increases collective competences and generates economies that are internal to the industry and external to firms. In turn, workers benefit from

\footnotetext{
${ }^{3}$ By competences are meant all those capabilities of economic agents that enable them, among other things: (i) to solve problems, (ii) to interact and work in teams and (iii) to switch between abstract and concrete thinking.
} 
upward occupational mobility as they are enabled to pursue their careers in other local businesses. Some of these authors see the movement of staff between different firms as being what distinguishes a production cluster from a mere concentration of businesses.

The interest in systems is partly due to concern among a number of social scientists with the role played by innovations and the creation of knowledge and capabilities in economic development. This school of thought has mainly focused on the study of national innovation systems, before turning to the relevant local, regional and sectoral aspects (Lundvall and Maskell, 2000). The starting point for these studies are the interactions between economic agents, which means that they do not confine themselves to analysing the internal behaviour of firms. Accordingly, emphasis is laid on the importance of systems in the innovation process, and not just firms and technology centres (Cooke, Gómez Uranga and Etxebarria, 1997; Freeman, 1995). As a result of the emphasis on interactions, consideration has been given to the existence of different types of production systems and of the specificity of knowledge creation processes within each of them.

Thus, some studies examine the scope for creating competitive advantages by producing and sharing knowledge within a production system (Bisang and others, 2004; Albornoz, Milesi and Yoguel, 2004; Yoguel, Novick and Milesi, 2003; Casalet,
Cimoli and Yoguel, 2005). One of the most virtuous network configurations is where there is geographical concentration with generation of externalities that promote collective efficiency and cooperation (Schmitz, 1995; Meyer-Stamer, 1998). Thus, while some systems tend to be less effective (Humphrey and Schmitz, 2000; Poma, 2000), others develop cooperative processes for learning and spreading tacit knowledge (Freeman, 1988; Camagni, 1991; Nonaka and Takeuchi, 1995).

Studies of the processes leading to the development of innovations within local production systems have also turned their attention to how knowledge creation and utilization capacities might be expanded. Progress has been made in differentiating the different modes of knowledge, with a distinction drawn between the codified and tacit kinds (Nonaka and Takeuchi, 1995; Johnson, Lorenz and Lundvall, 2002; Rullani, 2000). Studies have also evaluated the importance of the different forms of knowledge for the creation of competitive advantages by economic agents.

Lastly, various authors have developed templates that can be used not only to analyse groups of interrelated firms that are relatively concentrated in a single place, but also to tailor policies to them (Altenburg and Meyer-Stamer, 1999; Albuquerque, 2004; Wolfe and Gertler, 2004). Thus, for example, what are known as "production arrangements" are of particular interest in Brazil (Lastres, Cassiolato and Maciel, 2003; SEBRAE, 2002).

\section{III}

\section{Local innovation systems: conceptualization and some preliminary hypotheses derived from the Argentinean experience}

Considering the information given in the previous section, what we mean by a local innovation system is the space of interaction among firms and between firms and institutions in a common geographical location that includes relationships of both competition and cooperation. These systems are heterogeneous and have very different levels of complexity, depending on the number and characteristics of the actors and agents composing them and on the formal and informal links between them. Thus, a given system may be placed anywhere along a scale of situations ranging from the utmost virtuosity, with significant learning and creation of dynamic competitive advantages, to the other extreme in which both are practically non-existent.

What we mean to describe is not an ideal model whose variables already have established values. As we will show, our description will identify the key elements characterizing a system, but without setting a value upon them, as they vary from one system to another.

Local innovation systems encompass both production systems and education and training 
institutions, unions and professional associations and technological research and development bodies. All production systems have a local facet, leaving aside the fact that some include a variety of local organizations from a region, different regions in the same country or even different countries. Although there is no generally accepted definition of what constitutes the local sphere of a production system and no one procedure for identifying the geographical limits concerned, different authors and some national institutes of statistics have equated it with the local labour market.

Thus, a local production system can be delimited empirically by looking at people's daily movements from home to workplace. In Argentina, a unit has been proposed, the 'local economic area', to define them on the basis of these commuter journeys (Mazorra, Filippo and Schlesser, 2005; Borello and others, 2002 and 2004).

Analysis of local systems in Latin America generally, and Argentina in particular, reveals how little information is available on the most basic aspects of their morphology and functioning. This state of affairs may be due to the lack of researchers with a background in the subject, the low level of importance attached to the local sphere by much of the scientific and technical community, the lack of awareness of the importance of developing local systems, and a dearth of appropriate statistics, since the geographical units used by the bodies collecting information do not usually coincide with the areas concerned. There are also some deeper issues arising from the idea prevalent in many disciplines that the local sphere is unimportant in the workings of national or global systems. Thus, for example, while it is true that the economic sciences and sociology have concerned themselves with these problems, there are fields such as the economics of local systems and urban sociology that are still peripheral interests in these disciplines.

Besides these issues, the literature allows certain generalizations to be made about the workings of local innovation systems in Argentina (Borello, 2008; Borello and others, 2002 and 2004; Lugones and Sierra, 1999; Boscherini, Malet Quintar and Yoguel, 1997; Boscherini and Quintar, 1997; Boscherini, López and Yoguel, 1998; Yoguel and Boscherini, 1996 and 2001; Quintar and others, 1993; Rearte, Lanari and Alegre, 1997; Sepúlveda, 1999; Carmona, 2006; Sierra 2002; Yoguel and López, 2000; Yoguel, 2000). However, it is not possible to identify their common features without acknowledging the marked heterogeneity between them. This diversity is a central characteristic of systems of this type, both in their external facets and in their particular ways of working and nurturing knowledge.

The heterogeneity of local systems can be appreciated by analysing the following aspects: (i) the size and physical form of the system (measured in square kilometres, population, gross output); (ii) its characteristics in terms of the number of urban centres, composition of output, employment, etc.; (iii) the characteristics of public and private actors; (iv) the existence of translators; ${ }^{4}$ (v) the development of the public space; (vi) the type of institutional architecture (top-down, bottom-up or mixed); (vii) the degree of competition between economic agents; (viii) the scale of knowledge dissemination; (ix) understanding of the morphology, problems and potential of each system; (x) the level of knowledge appropriation by local actors; (xi) the rate of company creation and demise; (xii) circulation of workers and technical staff, among other things.

The existence of major differences in the aspects referred to complicates the task of establishing general rules for the functioning and characteristics of systems. Considering the information available in Argentina, however, it is possible to put forward a number of hypotheses reflecting their key features in the country.

(i) First, the way a local system operates can become either a constraint on the development of firms or a factor that enhances their growth and that of the society around them. Economic dynamism increasingly depends on the level of accumulated knowledge and experience, the skills and capabilities of human resources and the quality of institutions, the interaction between the different agents, research and development (R\&D) activities and the existence of economies of scale. Given that all these are interrelated, the characteristics of this relationship will determine the complexity of the system. Despite this, it is possible to affirm that the existence of linkages between agents who drive the development of learning and knowledgesharing processes is limited by the level of endogenous competences attained, both in firms and in institutions (Yoguel, Robert and Erbes, 2009).

\footnotetext{
${ }^{4}$ Translators are people who are capable of establishing a fruitful dialogue between different actors in a local system, such as business leaders and technology experts.
} 
(ii) Despite the above, the mere existence of well-functioning local systems does not do away with evolutionary differences between firms, as not all are capable of taking advantage of the virtuous institutional environment and positive externalities deriving from the proper functioning of a system with these characteristics. Generally speaking, firms with a lower level of competences tend to profit more from tangible externalities (such as trained labour and physical infrastructure) than from intangible externalities in the form of technological and market information and knowledge.

(iii) It is observed that agents (firms and institutions) require minimum competences without which it is hard for them to make good shortfalls in their knowledge, reduce strategic uncertainty, strengthen learning processes, counteract weaknesses in their organizational culture and, crucially, appropriate externalities generated in the local system. This minimum threshold of necessary competences rises as systems lose virtuosity. In a local system that produces positive externalities, less individual effort will be required by firms to achieve competitive advantages and quasi-rents in the market (Yoguel and Boscherini, 2001). In environments of this type, size is not an obstacle to firms gaining access, for example, to the benefits deriving from corporate cooperation agreements or public programmes of technological support.

(iv) Thus, when the local system generates positive externalities that economic agents can appropriate, the development of firms' capacity for innovation, and thence their competitiveness, does not depend (or depends less) on their size (Yoguel and Boscherini, 2001). In this case, the local system can act as a quasimarket that increases technical and organizational competences, favouring smaller agents. Thus, positive externalities counteract the competitive disadvantages arising from company size.

(v) The virtuous characteristics of a local system also depend on its institutional features. Thus, institutional development is a determining factor and also a reflection of the capacity of economic agents for innovation. The institutional environment is thus a basic factor in the generation of a public space that can facilitate the progress of the local system concerned. The creation of this public sphere is in itself a symptom of the degree of development attained, while at the same time it is the place where agents can improve their competences, whatever the initial differences in capacity between them. As a result of the collective character of the actions undertaken and the flow of formal and informal interactions between the different types of agents, large quantities of codified and tacit knowledge begin to be generated and circulated, contributing to the formation of individual and group competences and the creation of public goods and 'club' goods. Unlike public goods, the latter include knowledge that can be used to exclude those who are not members of the subsystem. More specifically, the knowledge, agreements and activities concerned are developed within a production complex and can benefit those agents belonging to it, but not outsiders. Consequently, these club goods constitute what Michael Storper calls "untraded interdependencies".

(vi) As in the case of firms, the existence of a lower degree of institutional development raises the minimum threshold of competences needed to take advantage of existing technological services, while technological cooperation never rises above a very low level. Again, local systems have great difficulty making codified knowledge tacit (i.e., territorializing it) and then recodifying it and making it global. Thus, it is essentially within individual firms that knowledge is spread and generated, without any institutional support or presence.

(vii) What the above shows is that the process of developing a local innovation system is neither simple nor automatic and requires the creation of translation mechanisms, as the agents involved speak different languages and operate by dissimilar logics and cultures. This variety of languages is a key institution in local systems, as important for their operation as banks, firms and universities (Poma, 2000). The great weakness of translation mechanisms partly explains the dearth of established interactions between the different types of agents.

(viii) The peculiarities developed by the agents and actors forming part of a system determine its idiosyncratic features. All actors in a local system have know-how that can be used as the basis for constructing new knowledge, although this stock varies greatly between and within different systems. This know-how is expressed through innovations and competences. The differences between economic agents in this respect and their understanding of what is new and important can give rise to problems of translation and interaction.

Added to the original differences between systems is their capacity to develop learning and knowledge construction and transformation processes, these latter being crucial for interpreting ever-greater economic 
uncertainty and complexity. In turn, these processes constitute the basis of a common stock of knowledge that underpins the homogenization and differentiation processes needed in the new competitive environment (Rullani, 2000). In this context, knowledge becomes valuable because of its potential to generate higher productivity, but also because it makes possible the interpretation of structural uncertainty. The scope for using it for one or the other purpose determines the characteristics of individual economies and the differences between them in terms of specialization to produce physical goods, goods that are fundamentally intangible or tangible goods with a high knowledge content (Poma, 2000). This last category is a core policy goal and a particularly great challenge for less developed countries, regions and systems.

(ix) In this context, a useful indicator of the functioning of a local system is its ability to identify and get the best out of hidden resources. Given that businesses need to make an effort to perceive and imagine changes before others do (Poma, 2000), their task consists in mobilizing what Hirschman (1967) calls the invisible component of the economy - defined as the ability to stimulate and organize hidden and overlooked resources and capabilities. Thus, territorial systems differ both in the latent resources available to them and in their ability to identify and benefit from these. In consequence, the way these latent or hidden resources are extracted or brought out comes to play a much more important role than the production of physical goods. Thus, the challenges of territorial development are greater still in cases where resources are not hidden but simply absent, whereas in virtuous local systems, which are composed of numerous agents and interactions, the invisible component of the economy is more easily made visible.

(x) Lastly, it needs to be stressed that the workings of local innovation systems partly depend on their production specialization profile, which determines certain basic characteristics of their virtuosity in the social and production spheres. The decision as to what to produce, quite apart from how, establishes the core activities that mark out the range of possibilities of a local system. Naturally, these activities are dynamic and changing. The specialization profile establishes parameters that are important for local development, such as the intangible component of the goods and services produced, the technology and division of labour in their production, the opportunities for opening up new technological frontiers on the basis of this interaction, and the composition of the workforce producing the goods concerned. The debate about the specialization profile, then, is also a discussion about the kind of society that is desired. In other words, what to produce and what to specialize in are economic decisions but also distributive ones that affect the scope for the local economy to generate learning processes and technological and industrial spillovers among the different agents composing it (Reinert, 2006). Viewed in this way, economic policy is also social policy.

The 10 positions put forward in the preceding paragraphs can be seen as working hypotheses relating to the functioning of local innovation and production systems in Argentina. Although they concern a particular country, a number of studies conducted in the region suggest that they could be extended to (and tested on) a variety of situations in Latin America.

Taken together, these hypotheses provide a framework for at least two more general considerations. First, the local development paradigm and toolbox assumes certain existing conditions that are found in some regions of European countries but do not necessarily obtain in Argentina. Second, while local institutions and production structures are fairly rigid and tend to be perpetuated over time, the present is not always a hypothesis of the future. The transformation of the urban structure in Argentina has opened a window of opportunity for qualitative improvement in local production systems. This can be inferred from certain studies showing the substantial absolute and relative growth of medium-sized cities since the 1950s (Vapñarsky and Gorojovsky, 1990; Vapñarsky, 1995). Many of them are now large enough to justify the introduction of certain public- and private-sector services and activities for which there would not previously have been a sufficient mass of users or consumers. 


\section{IV}

\section{Some general guidelines for analysing local innovation systems}

Considering the hypotheses presented in the previous section and the considerations they give rise to, the present section offers a set of general guidelines for analysing local innovation systems. This is a guide that identifies key aspects to be studied but does not specify the particular characteristics they acquire in each of the systems analysed.

This guide sets out to study local economic systems from a perspective that prioritizes aspects related to the construction of certain intangible elements such as the competences of economic agents, creativity and innovation capabilities and the creation and incorporation of knowledge. Thus, it represents one of the various possible ways of approaching and analysing local systems.

As mentioned, the list of factors to be considered derives from the characterization of local systems in the preceding pages, whose themes were organized into three major groups: core characteristics of local systems, institutional and interactional aspects, and statements and hypotheses relating to their functioning. The first two are concerned with more descriptive and general elements, while the third is essentially speculative and encompasses more specific issues. Lastly, we present some additional aspects that do not fall under any of the three points above, relating to the purpose, scope and existing resources of local systems and the availability of earlier information and studies to provide a basis for researching and analysing them.

\section{The characteristics of a local system ${ }^{5}$}

This section considers the characteristics of local systems defined as local economic areas (LEAs). When studying such systems, it is important to bear in mind their physical and organizational features and the peculiarities of their economic and employment structure, and to identify any constraints on their development. Analysing these aspects reveals the

\footnotetext{
${ }^{5}$ Some ideas in this section were taken from Borello and others (2004).
}

virtuosity of each system in terms of spillovers generated, and the potential for economic agents to increase their capabilities.

As regards the physical and organizational features of systems, consideration must be given to general characteristics and physical properties. The former are derived mainly from indicators revealing the structure of the system - urban nodes, approximate area of the LEA, number of municipal districts or departments and number of provinces involved - and the demographic dynamic (total population, intercensal growth rate). The latter concern internal and external connectivity, the existence of internal subsystems and the rural-urban mix, among other things.

When identifying the economic and employment structure of local systems, meanwhile, it is important to include the characteristics of the production dynamic in relation to output, the branches of activity that exist, the size of companies and the jobs generated, among other things. At the same time, it is necessary to consider the specialization profile, the level of linkage between firms of different sizes and their integration into the overall system, the leading economic and institutional agents and the degree to which the local system concerned is open or closed, i.e., its relations with the various external agents. It is also necessary to ascertain the dynamic of technological and organizational competence formation among the firms acting in this system, particularly in relation to size and the ability to capture externalities in the environment, so that their economic and employment performance can be explained. In relation both to these matters and to those described in the previous paragraph, economists and geographers have developed a variety of indicators that can be used to compare structures and systems (Goodall, 1987).

The constraints on the development of local systems are the other facet of the potential described above. Although they can be identified in various ways, the following are important when the development of learning and knowledge generation processes is at issue: (i) centralization of production activities and decision-making, (ii) financial constraints that prevent development processes from being implemented and 
(iii) a lack of structures for creating awareness about the importance of local systems in the creation of competitive advantages and the implementation of programmes that can help to improve the competences of individuals, firms and institutions.

\section{Institutions and interrelationships within a local system}

As was mentioned in the hypotheses presented in the third section, the capacity-building efforts of systems and private agents need to be complemented by the generation of institutional capabilities. Accordingly, two central issues need to be considered.

First, to characterize any local system it is necessary to identify and describe local institutions involved with production activities. In particular, there needs to be knowledge of their structure and functionality and of the presence of programmes and projects that allow the knowledge possessed by institutions to connect with that of firms and other organizations. This reveals the degree of publicprivate engagement. Again, it is indispensable to formulate local policies from a perspective broader than that of local agents, centring rather on networks of firms, human resource development and local needs. Furthermore, it is necessary to understand the characteristics of evaluations of the way these programmes and institutions work.

Secondly, in describing the system it is necessary to provide an appreciation of the importance acquired by a range of tangible and intangible elements that define its virtuosity. These include the variety of languages; the public and private actors who operate within this variety, allowing information and knowledge to be shared; the circulation of human resources, and thus knowledge; endogenous competences, their "systemicity" and thence the homogeneity or heterogeneity of economic agents; and the public space.

\section{The dynamic and workings of local systems}

The way systems work and their importance for local development can be assessed from a number of aspects associated with the dynamic of their institutional and production characteristics. For one thing, it is important to be aware of the importance of the role assumed by the local system in promoting the competitiveness of firms, reducing uncertainty for economic agents and increasing their technical and organizational skills, while generating externalities that compensate for the differences between them. Here, it is necessary to know what the minimum threshold of competences is if knowledge creation and dissemination processes are to exist.

Again, the importance of the local system as a space that promotes interaction and integration of knowledge can also be evaluated on the basis of the existence and characteristics of institutional and production networks. In this context, it is crucial to analyse the innovation functions developed by the most dynamic institutions and agents. The active presence of both and the ability to spread knowledge to the rest of the system are important elements in the latter's learning and production processes. It is also necessary to evaluate the system's potential to mobilize the invisible component of the economy, i.e., to locate and organize hidden resources.

From an institutional perspective, consideration must be given to the importance the different subject areas are acquiring in the local development agenda. Here, differences can be observed in the dynamics of systems depending on the priority given in public-sector policies to efforts to promote institutional development and relations between the public and private sectors and between privatesector actors, to create knowledge-based competitive advantages, to train translators and to influence the complexity and internationalization of networks, among other things.

The issues raised in the three parts of this section are meant to provide a summary of the main elements to be considered when analysing the importance of local systems as spaces for generating knowledge and competitive advantages. The rest of this paper will present some suggestions for policies that it is believed would improve the aspects discussed and enhance innovation systems. 


\section{V}

\section{Some suggestions for policies to promote local systems}

In the previous sections, we carried out a stylized analysis of the idea of a local innovation system, treating it as a gradient of the situation in which specific systems are placed in respect of the degree of development of all the elements used to characterize them. This section, unlike the previous ones, is essentially propositional. It identifies the premises and assumptions on which policy recommendations are based, describes jurisdictional and real aspects affecting policy deployment and reviews core problems and proposals for action.

\section{Premises and suppositions relating to local systems and policies}

The premises and assumptions on which local system policymaking is based include some metapolicy aspects, clearly revealing the experimental character that intervention should assume and identifying a number of key elements for implementation.

Where metapolicy issues are concerned, the application of a public policy designed to improve the workings of local innovation systems presupposes the existence of three conditions for intervention (Yoguel, 2003). First and foremost, proper financing is needed. Although this is not the only requirement, it is a necessary condition that is often overlooked in policy design in Argentina. Second, awareness-raising measures need to be implemented in advance, as do actions to ensure the participation of all local agents and actors in policy design and implementation. Lastly, it is necessary to create or strengthen a system of coordinated decentralization and intelligence in which local agents and actors can make known their interests and ideas, thus providing opportunities for policy transmission and generating a specifically local set of institutions (voice, in Hirschman's sense). It is important to create a public space in which interaction between different agents is encouraged, and this means identifying both the areas that favour this and those that hinder the sharing of information and knowledge.

Another key element of metapolicy is to identify regressive local coalitions that constrain both the dynamic of structural change in the region and the generation and spread of learning processes. Here, a central policy objective should be to activate autonomous locally-based agents who can help to form progressive coalitions. According to the logic of Bianchi and Miller (2000), progressive coalitions depend on the existence and creation of complementarities, manifested in production chains and the different linkages between private and public agents.

In an evolving, globalized economy, policy needs to be experimental and to undergo regular review and modification, which means that the metapolicy elements referred to above are crucial. In particular, they should make it possible to clear the blockages identified and support the development of progressive alliances, so that agents and actors come to inhabit the territory rather than merely being lodgers in it. A degree of institutional stability is necessarily required for alliances of this type to exist and develop (Bianchi and Miller, 2000).

The position set out in the preceding paragraphs assumes the presence of certain minimum conditions in terms of income, access to decent housing and public services and infrastructure, so that policy actions can be oriented towards the creation of capabilities and the satisfaction of needs over and above the primary ones of food, health care and access to certain basic public goods. This need for a certain minimum basis holds not just for tangible matters like those mentioned, but also includes justice in a broad sense (social, environmental and territorial).

Setting out from these minimum conditions, key policy elements should be aimed at developing the institutional system, the production environment for economic agents, production networks and the different types of production chains, human resources and an organization of labour that facilitates the generation of learning and knowledge-sharing processes. Differences between systems translate into particular configurations that are reproducible only in part and that consequently require policies tailored to the specific characteristics of the context. These considerations show how important it is to follow an approach aimed at ascertaining needs and generating 
responses on the basis of the guidelines proposed in the fourth section of this paper.

The idea is to turn the local sphere into a space where dynamic rather than static competitive advantages can be created, with priority given to the efficiency of physical and cognitive infrastructure; where good use can be made of information and knowledge that is external in origin but can be internalized (homeostatic processes); where endogenous innovation dynamics can be developed in local systems (autopoietic processes); and where specific competences can be generated. In sum, policies should generate self-regulation mechanisms and levels of systemic autonomy that lead to evolutionary learning. This would permit the creation of the internal conditions needed to improve the system, together with strategies aimed, firstly, at establishing new institutions or functionally reforming existing ones and, secondly, at generating models favouring the development of an environment that facilitates the incorporation of local firms into the global space.

To complement this, there is a need to consider other aspects that are vital for an understanding of the dynamic of local systems and to formulate policies that can strengthen them. First and foremost, policies need to set out from the cultural elements that identify the local system, which means recognizing the diversity of idiosyncratic behaviours, evolutionary paths and production arrangements that limit the scope for mechanically reproducing measures applied in other local systems.

Second, it is necessary to build upon the existing basis, i.e., of institutions, programmes and policies that are already in progress. Furthermore, there are often projects, laws, activities and private-sector actions oriented towards resolving the difficulties that can arise in a system. Failure to acknowledge this background and act accordingly practically guarantees that the same obstacles will arise. The atomization of actions and policies bearing upon a single issue is a characteristic of much policymaking and policy implementation in Argentina and other countries. Existing activities are a good laboratory for evaluating measures that work and for making progress in this area.

Third, it is necessary to develop a sequence of stages and to plan actions out, although these must be preceded by a minimum diagnosis of the starting situation. Not all the data need necessarily be available, so that while a good policy will always advance into unknown areas, a minimum of prior knowledge is required.
Fourth, and following on from the previous point, the measures implemented need to include research and action mechanisms that, reflecting the experimental character of policies, make it possible to collect information about their implementation and the level of participation among the agents involved.

Lastly, the technical rationality entailed in the two previous aspects should not be divorced from the political need to achieve immediate results in the short term (two years). In other words, the first condition for a policy to be at all effective is that it continue to exist over time. This requires a technical effort to prioritize measures and be selective about the actions undertaken.

\section{Jurisdictional and real aspects of problems and policy implementation on the ground}

In designing actions, it is essential to be aware of the irregularities that define and establish the way problems and policies develop on the ground. In the first place, it is necessary to consider the geographical extent of the local system and the administrative jurisdictions operating in the territory concerned. To operate in local systems, coordinated action may be required by different municipal and provincial governments. ${ }^{6}$ In the second place, it is important to understand the sphere in which these processes actually operate.

From the standpoint of jurisdiction, it is necessary to understand the juxtaposition of municipal, provincial and national powers within each local system. In Argentina, the heterogeneity of the legal powers belonging to the provinces is compounded by the existence of over 2,000 municipal governments (communes, communal councils and others) that differ greatly from one another. However, while the administrative authorities guide and orient innovation processes, these need to be analysed in their actual sphere of application.

Another system that should be identified is that of local production clusters and networks, as this provides an overview of all the activities and institutions that interconnect vertically or horizontally to produce goods, services or both, and to generate the processes of innovation and knowledge creation

\footnotetext{
${ }^{6}$ In almost all the local systems of Santa Fe Province, for example, coordination is required between at least one municipal government and the provincial government, since the rural areas around the municipalities come under provincial jurisdiction.
} 
and use that go with production. The elements and interactions composing a network often extend beyond the jurisdictional limits previously identified, although it may often be found that most of the activities of a particular network are centred on a local system. It needs to be recalled, however, that in Argentina as in other countries, the geographical concentration of firms that carry out similar activities does not necessarily imply a close relationship between them.

Local areas, lastly, are part of regional spaces. It is difficult to define exactly what the limits of regional innovation systems are, as these need to be established on the basis of information that is not always fully and systematically available. In countries like Argentina, the regional innovation level, which often encompasses a number of provinces and local systems and may extend for hundreds of kilometres, may be the most interesting to understand and manage.

\section{Identifying and characterizing core problems and policy proposals}

Some of the core problems that can be considered in relation to the development of local innovation systems are the level of endogenous competences among local economic agents; interaction among firms, and between these and institutions; and the integrated functioning of local and regional systems.

\section{a) The competences of agents}

A number of problems with local innovation systems are due to the limited competences of both firms and institutions. In business organizations (chambers of commerce and business associations), but also in the 'third sector' (social, neighbourhood and non-governmental organizations), there is a lack of professionalization and the technical and professional staff available are few and undertrained. Difficulties are also encountered in generating new individual and collective routines in firms and institutions, and the number of public and private actors is small.

Proposals for solving problems of this type require the construction of a taxonomy of situations that are differentiated by the importance of the constraints described. A vital starting point in local innovation systems that are at the lowest levels of the gradient is to carry out activities to raise awareness of the importance of increasing the competences of agents and institutions. Given that the value of such measures is often not appreciated in many of these local systems, progress will only be made with these activities if the subject is first placed on the discussion and working agendas of firms and institutions. In local systems where awareness-raising has already taken place, action should begin with a self-diagnosis of the specific problems of agents and actors so that they have systematized information available to reflect on their own practices. In this case, awareness-raising measures can only be implemented after identifying people and institutions capable of helping economic agents to prepare diagnoses and self-assessments, bearing in mind the diversity of existing situations. Actions oriented towards private-sector agents would have to be accompanied by institutional self-diagnoses that yielded information about their shortcomings when it came to formulating and implementing development programmes. It is also necessary to create appropriate incentives to encourage the incorporation of technical and professional staff into the institutions comprising the local system.

In many local innovation systems, efforts to find new ways of financing the expenditure involved in operating chambers of commerce are vital if institutions of this type are to play a proactive role in developing economic agents' competences. Given that the lack of resources and the limited representativeness of these organizations are a major obstacle to the generation of services for firms (Borello, 2008), there seems to be a need for new systems of public-private financing. In cases where a longer process of diagnosis and reflection on the workings of the local innovation system has taken place, the need to establish new institutions or modify existing ones may already have been identified. For example, intermediate or 'bridging' institutions with public and private representation may be crucial for generating effective processes of knowledge production, circulation and appropriation.

Constraints on the development of endogenous competences also arise from the characteristics of public policies oriented towards this objective. In particular, it is difficult for economic agents to identify and take advantage of the policy instruments that exist. In this context, policy actions ought to turn upon at least three core issues. First, there is a need to ensure policy instruments are accessible to local agents by simplifying procedures and creating a onestop shop for provision. The availability and scope of these instruments are critical. Second, it is necessary to rethink existing policies and mechanisms in the light of the needs and development of local competences. This need stems directly from the difficulties involved in applying universal policies and from the marked 
heterogeneity of systems. Third, there is a need to develop tools and spaces for evaluating existing policies, with the participation of both policymakers and users. It will be vitally important not only for evaluation to be carried out after policies have been applied, but for there to be ongoing monitoring of these during the implementation process.

\section{b) Interaction between agents}

With respect to interaction among economic agents, and between these and institutions, it is once again possible to identify a series of needs that apply to all local systems, although without overlooking the differences in terms of the importance they assume in each.

One issue here is the inadequate presence and coordination of institutions and economic agents in the public space, as a result of which knowledge is shared between them only sporadically or not at all. This is partly due to the lack of emphasis on outreach, applied research and dissemination activities in the programmes of universities, technology centres and secondary and tertiary vocational training institutions.

A variety of policies ought to be applied here, all with the goal of enhancing the interaction between the different types of agents making up the local system. For this, awareness-raising measures notwithstanding, what is primarily required is to change outlooks and cultures in which there is no settled tradition of collaborative behaviour. Secondly, measures are needed to foment the creation of networks involving agents of different types and sizes (firms, institutions, chambers of commerce, etc.), and this will require the presence of linking agents and incentives to integrate systems of collaboration that help to enhance competences. This entails a twofold plan of action encompassing both the creation of new ties and the formalization of existing ones and designed specifically to strengthen the public goods and club goods of local chains. Thirdly, it is also indispensable from the public policy standpoint to formulate strategic plans that operate in the main production networks, involving all public and private actors. Among other issues, strategic planning serves to reduce the uncertainty surrounding the orientation of public policies on the basis of the information that exists about priority issues and their promotion.

Important though it is, increasing interactions between economic agents is not an automatic process. On the contrary, the diversity of goals and languages with which different types of agents operate, even within a homogeneous local system, requires the presence of linking agents. This being so, a major weakness that can hinder the development of a local system is the lack of translators in technical and competence-building areas, and of network integrators and organizers.

In this situation, the needful lines of action centre on the training of human resources with an aptitude for translation and organization. Their main characteristic should be the ability to converse both in the languages of the business world and in those of science and technology, and their main task would be to bring these different worlds together to facilitate the creation of knowledge networks. How human resources of this type are to be developed also differs significantly depending on the local system concerned. In the first place, the need for translators must be based on the characteristics of each system. This means determining the areas in which there are specific gaps and applying measures to create the relevant capabilities in order to make better use of internal system synergies and improve the capacity for absorbing knowledge generated externally. After this, training programmes need to be created to train local translators, organizers and integrators on the model of those found naturally within the system. It is important to systematize what these people know and combine it with other knowledge derived from regional or national experience in this area.

\section{c) Integrating local and regional systems}

In addition to those described above, it is also possible to identify core problems associated with the integrated functioning of local and regional systems.

Here, one of the problems detected in most of the studies reviewed has been a failure to make awareness of the importance of knowledge and the local sphere part of the relevant discussion agenda. This affects local systems very unequally. For less developed ones, awareness-raising among local agents and actors is critical. One initiative might be to include these subjects in the syllabuses of schools, universities and tertiary vocational training institutions. In more developed systems, awareness-raising measures could centre on the promotion of academic, corporate and artistic events that contribute to a greater understanding of the importance of these issues, and on financial support for forums, conferences and other such events to bring together people from different institutions.

Another of the problems detected is the lack of the kind of specialization in production activities that would bring increasing returns to scale, generate spillovers and increase the scope for appropriating 
quasi-rents from innovation efforts that are mainly carried out independently by economic agents. The scope of the measures that might be applied also depends on the development level of local systems.

A crucial starting point in less developed systems is to establish the possibility of creating a new economic specialization, based on existing activities and the characteristics of goods and services demand that is unmet locally. One thing that is required here is to recognize creative and commercial capabilities and promote them in training activities already under way, so that they can then be deliberately introduced into local firms and institutions. The idea is to capture and exploit not only the organized capabilities of the latter, but the potential of people trained in the area. Actions of this type may serve to reverse the exodus and outflow of skilled people. In more developed systems, consideration could be given to orienting major national and international negotiations towards the promotion of their new investment projects. In those that have the requisite starting capabilities, a long-term approach should be taken to fostering the development of activities that are faster-growing nationally and globally, examples being business and environmental services, tourism, new materials and design.

The workings of local systems are also affected by the difficulty of detecting and prioritizing physical investment needs. As with other aspects dealt with in earlier paragraphs, it is not easy to carry out a diagnosis. The various decades of crisis in Argentina and other countries of Latin America seem to have reduced their ability to contemplate and devise new projects involving substantial investment. To improve the workings of local innovation systems, it may be necessary to reconstruct planning arrangements for identifying and characterizing the physical investments that are essential at every level —national, provincial and municipal - of the State machinery.

It is possible that the measures set out in earlier paragraphs may be difficult to apply because of the pronounced internal heterogeneity that usually characterizes local innovation systems. This is due to the presence of inequalities that prevent transformative actions from being formulated. Accordingly, the first step is to identify and define these inequalities. The next is to take advantage of imbalances in the local system itself and promote the spread of knowledge by means of contacts between people and institutions with different capabilities. Lastly, there needs to be positive discrimination between individuals, groups, institutions, neighbourhoods and localities when public resources are allocated, so that capabilities and new institutions can be generated in the most disadvantaged areas.

For all the importance of the matters brought up here so far, it should be made clear that the workings of local innovation systems do not depend solely on their internal dynamic, but also on their relationship with other systems. Being either too open or too closed to the contributions of neighbouring systems or regions, and indeed of other regions and systems around the world, is an obstacle to the development of local systems. In other words, a degree of balance is required.

To achieve this, it is necessary to pursue versatile integration into the global system, working with whatever degree of openness or reserve is needed for knowledge feedback within the system to boost its development. This means building up the capacity to read and interpret the regional, national and international scenes in different areas: trade and technology; the field of more general scientific knowledge, which can only be decoded, however, by a body of agents with specific cognitive capabilities; and the more general field of codifying business competences.

For local innovation systems to work better, lastly, a solution needs to be found to problems associated with a lack of knowledge and statistics describing them. Although this is quite an ambitious objective in the context of Latin American statistical systems, which are still hard put to it to generate proper economic and sociodemographic information, it is essential to have some aggregates that provide a picture of the dynamic of the system as a unit of analysis. The implementation of policies whose development effects are positive requires prior diagnostic processes, which are very hard to carry out without certain basic information. For this reason, there is a need for sustained progress in the following areas: (i) conducting research to delimit, identify and characterize local and regional economic systems and their innovation dynamic; (ii) undertaking research to identify knowledge gaps in systems; (iii) establishing mechanisms to promote research involving different technical, educational and business institutions in different places; (iv) fostering the creation of national statistical databases that allow a comparative study to be made of local systems, such as the Database for the Study of Employment Dynamics (BADE) of the Ministry of Labour, Employment and Social Security and the SME Map of the Secretariat of Industry, both in Argentina; and (v) promoting the construction of local information systems (Borello, Gajardo and Bettatis, 2003). 


\section{VI}

\section{Final considerations}

The present article has presented a brief systematization of a number of ideas about the workings of local innovation systems in Argentina. Setting out from this, it has sought to define a range of aspects that are critical to the analysis of such systems and the measures that would have to be applied to improve them. It must be emphasized, however, that the general description of fields of analysis and policies does not detract from the importance of specific measures, given the heterogeneity of existing situations. Accordingly, the proposals put forward are simply guidelines for identifying the needs and the spheres of action that ought to be specified in the light of the dynamic and characteristics of the different systems.

Much of what has been proposed in this paper represents a major challenge for the different people and institutions involved in the science and technology system and for the public- and private-sector bodies involved with production activities. This is because our conception and comprehension of how local systems operate and what their problems are is not confined to technical and operational issues: the importance of political and cultural aspects is recognized, even if they are not at the centre of the analysis. From a technical standpoint, it is essential to strive to produce more and better statistics for local and regional analysis. However, this task cannot be contemplated in isolation from the need to train people to use (and demand) this information in more sophisticated ways. The difficulty of generating appropriate data and more advanced research is partly due to the political aspects that permeate a number of the issues raised in this study, among them the need to create public spaces and spheres of discussion. Local research will only improve if we strengthen the capacity to conduct it. Once again, an issue that might seem to be purely technical cannot be resolved without confronting regressive local coalitions that often have regional or national support.

The limits of the possible, even in difficult situations, can be extended or expanded still further when support is forthcoming from national or provincial institutions whose general goals in terms of promoting and improving local innovation and production systems are similar. Neither the State, nor employers' organizations, nor institutions are monolithic, fossilized entities. There are institutions from which initiatives like the ones proposed in this study can come, even in a context of fragile and sometimes incomplete democracies.

(Original: Spanish)

\section{Bibliography}

Albadalejo, M. and H. Romijn (2000), "Determinants of innovative capability in small UK firms: an empirical analysis", Working Paper, No. 13, Eindhoven, Eindhoven Centre for Innovation Studies.

Albornoz, F., D. Milesi and G. Yoguel (2004), "Tramas productivas en viejos sectores: metodología y evidencia en la Argentina", Desarrollo económico, vol. 43, No. 172, Buenos Aires, Institute of Economic and Social Development.

Albuquerque, F. (2004), "Local economic development and decentralization in Latin America", CEPAL Review, No. 82 (LC/G.2220-P), Santiago, Chile.

Altenburg, T. and J. Meyer-Stamer (1999), "How to promote clusters: policy experiences from Latin America", World Development, vol. 27, No. 9, Amsterdam, Elsevier.

Becattini, G. (1990), Modelli locali di sviluppo, Bolonia, Il Mulino.

Bellandi, M. (1989), "Capacità innovativa difusa e sistema locali di imprese", Modelli locali di sviluppo, G. Becattini (ed.), Bolonia, Il Mulino.
Bianchi, P. and L. Miller (2000), "Innovación, acción colectiva y crecimiento endógeno: un ensayo sobre las instituciones y el cambio estructural", Territorio, conocimiento y competitividad de las empresas: el rol de las instituciones en el espacio global, Fabio Boscherini and Lucio Poma (ed.), Madrid, Editorial Miño y Dávila.

Bisang, R. and others (2004), "Las redes de producción y el empleo. Elementos básicos para la formulación de políticas públicas", Lima, ILO Regional Office for Latin America and the Caribbean, unpublished.

Boisier, S. (2004), "Desarrollo territorial y descentralización: el desarrollo en el lugar y en las manos de la gente", EURE (Santiago), vol. 30, No. 90, Santiago, Chile, Catholic University of Chile, September.

Borello, J.A. (ed.) (2008), Aproximaciones al mundo productivo de la Región Metropolitana de Buenos Aires, Los Polvorines, Universidad Nacional de General Sarmiento.

Borello, J.A., R. Fajardo and C. Bettatis (2003), "Pautas para el 
relevamiento y la sistematización de la información: sistema de información económica local (SIL) en la microregión de San Justo-San Javier (Santa Fe), en el partido de Olavarría (Buenos Aires) y en Esquel y la Comarca de Los Alerces (Chubut)", Buenos Aires, Programa de Desarrollo Local y Competitividad de Pequeñas Empresas, IADB.

Borello, J.A. and others (2004), “¿Qué es lo local en la Región del Gran Buenos Aires? Elementos para definir unidades subregionales que sean útiles para encarar acciones de desarrollo local, con énfasis en el empleo", Programa Área, International Labour Organization, Buenos Aires, unpublished.

(2002), "Áreas económicas locales: criterios para su definición en la Argentina", Santiago, Chile, Economic Commission for Latin America and the Caribbean (ECLAC), unpublished.

Boscherini, F. and A. Quintar (1997), "El problema del desempleo y el rol de los microemprendimientos y de las microempresas: reflexiones a partir de algunas experiencias locales”, Boletín informativo Techint, No. 290, Buenos Aires, Techint.

Boscherini, F., M. López and G. Yoguel (1998), "Sistemas locales de innovación y el desarrollo de la capacidad innovativa de las firmas: un instrumento de captación aplicado al caso de Rafaela", Documento de trabajo, No. 10, Los Polvorines, Universidad Nacional de General Sarmiento.

Boscherini, F., N. Malet Quintar and G. Yoguel (1997), "Consideraciones acerca del ambiente y el desarrollo de capacidades innovativas de las firmas", document presented at the Red Pymes-Mercosur Annual Meeting, La Plata.

Camagni, R. (ed.) (1991), Innovation Networks: Spatial Perspectives, London, Belhaven Press.

Capello, R. (1999), "Spatial transfer of knowledge in high technology milieux: learning versus collective learning processes”, Regional Studies, vol. 33, No. 4, London, Taylor \& Francis.

Carmona, R. (2006), Instrumentos de política industrial y fomento productivo en el desarrollo económico local. Estudios de caso en los municipios de la Zona Noroeste de la Región Metropolitana de Buenos Aires, Los Polvorines, Universidad Nacional de General Sarmiento.

Casalet, M., M. Cimoli and G. Yoguel (2005), Redes, jerarquías y dinámicas productivas, Buenos Aires, Editorial Miño y Dávila.

Cooke, P., M. Gómez Uranga and G. Etxebarria (1997), "Regional innovation systems: institutional and organisational dimensions", Research Policy, vol. 26, No. 4-5, Amsterdam, Elsevier.

Coraggio, J.L. (1987), "Los complejos territoriales dentro del contexto de los subsistemas de producción y circulación", Textos, No. 2, Quito, Ciudad.

Dahl, M. (2002), "Embedded knowledge flows through labor mobility in regional clusters in Denmark", document presented at the DRUID Summer Conference on Industrial Dynamics of the New and Old Economy, Elsingore, Denmark, June [online] http://www.business.auc.dk

Ernst, D and A. Lundvall (1997), "Information technology in the learning economy: challenges for developing countries", DRUID Working Papers, No. 97/12, Copenhagen, Danish Research Unit for Industrial Dynamics (DRUID).

Fernández, Víctor R., Ash Amin and José I. Vigil (2008), Repensando el desarrollo regional. Contribuciones globales para una estrategia latinoamericana, Buenos Aires, Editorial Miño y Dávila.

Fredriksson, C.G. and L.G. Lindmark (1979), "From firms to systems of firms: a study of interregional dependence in a dynamic society", Spatial Analysis, Industry and the Industrial Environment, F. Hamilton and G. Linge (ed.), New York, Wiley.

Freeman, C. (1995), Long Waves in the World Economy, Aldershot, Edward Elgar.

(1988), “Japan: a new national system of innovation?", Technical Change and Economic Theory, G. Dosi and others (eds.), London, Pinter.

Fröbel, F., J. Heinrichs and O. Kreye (1980), The New International Division of Labour: Structural Unemployment in Industrialised Countries and Industrialisation in Developing Countries, Cambridge, Cambridge University Press.

Gereffi, G. and M. Korzeniewicz (1990), "Commodity chains and footwear exports in the semiperiphery", Semiperipheral States in the World-Economy, W. Martin (ed.), Westport, Greenwood Press.

Goodall, B. (1987), The Penguin Dictionary of Human Geography, New York, Penguin Books.

Gorenstein, S. (1993), "El Complejo Petroquímico Bahía Blanca: algunas reflexiones sobre sus implicancias espaciales", Desarrollo económico, vol. 32, No. 128, Buenos Aires, Institute of Economic and Social Development.

Groenewegen, P. (1987), "Division of labour", The New Palgrave: A Dictionary of Economics, J. Milgate and P. Newman (eds.), London, MacMillan.

Hirschman, A. (1967), The Principle of the Hiding Hand, Washington, D.C., Brookings Institution.

(1958), The Strategy of Economic Development, New Haven, Yale University Press.

Holmes, J. (1986), "The organization and locational structure of production subcontracting", Production, Work, Territory, A. Scott and M. Storper (eds.), Boston, Allen \& Unwin.

Hopkins, T. and I. Wallerstein (1986), "Commodity chains in the world economy prior to 1800 ", Review, vol. 10, No. 1.

Humphrey, J. and H. Schmitz (2000), "Governance and upgrading: linking industrial cluster and global value chain research", Working Paper, No. 120, Sussex, Institute of Development Studies.

Johnson, B., E. Lorenz and B-A. Lundvall (2002), "Why all this fuss about codified and tacit knowledge", Industrial and Corporate Change, vol. 11, No. 2, Oxford, Oxford University Press.

Lall, S. (1992), "Technological capabilities and industrialization", World Development, vol. 20, No. 2, Amsterdam, Elsevier.

Lastres, H., J. Cassiolato and M. Maciel (2003), "Systems of innovation for development in the knowledge era", Systems of Innovation and Development, J. Cassiolato, H. Lastres and M. Maciel (eds.), Cheltenham, Edward Elgar.

Lifschitz, E. (1986), Bloques sectoriales: partición de los cuadros de insumo-producto correspondientes a las actividades productoras de bienes, Buenos Aires, Secretaría de Planificación de la Nación.

Lugones, G. and P. Sierra (1999), "Políticas para la consolidación de los sistemas locales de innovación", Boletín informativo Techint, No. 299, Buenos Aires, Techint. 
Lundvall, B. and P. Maskell (2000), "Nation states and economic development: from national systems of production to national systems of knowledge creation and learning", The Oxford Handbook of Economic Geography, G. Clark, M. Feldmann and M. Gertler (eds.), Oxford, Oxford University Press.

Maskell, P. and A. Malmberg (1999), "Localised learning and industrial competitiveness", Cambridge Journal of Economics, vol. 23, No. 2, Oxford, Oxford University Press.

Massey, D. (1995), Spatial Divisions of Labour: Social Structures of the Geography of Production, London, Macmillan.

Markusen, A. (1995), "Sticky places in slippery place: a typology of industrial districts", Economic Geography, vol. 72, No. 3, Worcester, Clark University.

(1994), "Studying regions by studying firms", Professional Geographer, vol. 46, No. 4, Washington, D.C., Association of American Geographers.

Marshall, A. (1890), Principles of Economics, London, MacMillan.

Mazorra, X., A. Filippo and D. Schlesser (2005), “Áreas económicas locales y mercado de trabajo: estudios de tres casos", Desarrollo productivo series, No. 157 (LC/L.2151-P), Santiago, Chile, Economic Commission for Latin America and the Caribbean (ECLAC). United Nations publication, Sales No. S.04.II.G.79.

Meyer-Stamer, J. (1998), "Path dependence in regional development: persistence and change in three industrial clusters in Santa Catarina, Brazil", World Development, vol. 26, No. 8, Amsterdam, Elsevier.

Morgan, K. (1995), The Learning Region: Institutions, Innovation and Regional Renewal, Cardiff, University of Wales.

Nomisma (1993), Innovazione e ricerca. Potenzialita' e vincoli del sistema industriale dell'Emilia-Romagna, Bolonia, Laboratorio di Politica Industriale.

Nonaka, I. and H. Takeuchi (1995), The Knowledge-Creating Company: How Japanese Companies Create the Dynamics Of Innovation, Oxford, Oxford University Press.

Piore, M.J. and C.F. Sable (1984), The Second Industrial Divide: Possibilities for Prosperity, New York, Basic Books.

Poma, L. (2000), "La nueva competencia territorial”, Territorio, conocimiento y competitividad de las empresas: el rol de las instituciones en el contexto global, F. Boscherini and L. Poma, Buenos Aires, Editorial Miño y Dávila.

Power D. and M. Lundmark (2004), "Working through knowledge pools: labour market dynamics, the transference of knowledge and ideas and industrial clusters", Urban Studies, vol. 41, No. 5/6, Thousand Oaks, Sage Publications.

Quintar, A. and others (1993), "Rafaela, un cuasi-distrito italiano 'a la argentina", Documento de trabajo, No. 35, Buenos Aires, ECLAC office in Buenos Aires.

Rearte, A., E. Lanari and P. Alegre (1997), Sistemas de innovación y el desarrollo de la capacidad innovativa de las firmas: el caso de Mar del Plata, Mar del Plata, Universidad Nacional de Mar del Plata.

Reinert, S. (2006), "European integration innovation and uneven economic growth: challenges and problems of EU 2005", Working Papers in Technology Governance and Economic Dynamics, No. 5, Tallinn, Tallinn Technical University.

Rofman, A. (1984), "Subsistemas espaciales y circuitos de acumulación regional", Revista interamericana de planificación, vol. 18, No. 70, Mexico City, Servicio de Información Agroalimentaria y Pesquera (SIAP).

Rullani, E. (2000), "El valor del conocimiento", Territorio, conocimiento y competitividad de las empresas: el rol de las instituciones en el contexto global, F. Boscherini and L. Poma, Buenos Aires, Editorial Miño y Dávila.

Saxenian, A. (1996), Regional Advantage: Culture and Competition in Silicon Valley and Route 128, Cambridge, Harvard University Press.

Sayer, A. and R. Walker (1992), The New Social Economy: Reworking the Division of Labor, London, Basil Blackwell.

Schmitz, H. (1995), "Collective efficiency: growth path for smallscale industry", Journal of Development Studies, vol. 31, No. 4, London, Taylor \& Francis.

Scott, A. (1993), Technopolis: High-technology Industry and Regional Development in Southern California, Berkeley, University of California Press.

(1988), Metropolis: From the Division of Labor to Urban Form, Berkeley, University of California Press.

(1986), "Industrial organization and location: division of labor, the firm, and spatial process", Economic Geography, vol. 62, No. 3, Worcester, Clark University.

(1983), "Location and linkage systems: a survey and reassessment”, Annals of Regional Science, vol. 17, No. 1, Heidelberg, Springer Berlin.

SEBRAE (Brazilian Service of Support for Micro and Small Enterprises) (2002), Promoção de arranjos produtivos e innovativos no Brasil, Helena M. Lastres and others (coords.), Brasilia, Brazilian Service of Support for Micro and Small Enterprises/National Council for Scientific and Technological Development/Financiadora de Estudos e Projetos, S.A. (SEBRAE/CNPq/FINEP).

Sepúlveda Ramírez, L. (1999), "Construyendo política industrial. Enfoque socioeconómico aplicado a un estudio regional", thesis, Los Polvorines, Instituto de Industria, Universidad Nacional de General Sarmiento.

Sierra, P. (2002), "Políticas para la consolidación de los sistemas locales de innovación en la Argentina", Revista iberoamericana de ciencia, tecnología, sociedad e innovación, No. 4, Buenos Aires, Organization of Ibero-American States for Education, Science and Culture.

Smith, D. (1981), Industrial Location: An Economic Geographical Analysis, New York, John Wiley \& Sons.

Stambol, L.S. (2003), "Urban and regional labour mobility performance in Norway", ERSA Conference Papers, No. 3, Jyvaskyla, Finland, European Regional Science Association.

Storper, M. and R. Walker (1989), The Capitalist Imperative: Territory, Technology, and Industrial Growth, New York, Basil Blackwell.

Taylor, M. and N. Thrift (1983), "Business organisation, segmentation and location", Regional Studies, vol. 17, London, Taylor \& Francis.

Truel, J. (1983), "Structuration en filière et politique industrielle dans l'électrique: une comparaison internationale", Revue d'économie industrielle, vol. 23, No. 1, Paris, Centre national de la recherche scientifique (CNRS).

Vapñarsky, C. (1995), "Primacía y macrocefalía en la Argentina: la transformación del sistema de asentamiento humano desde 1950", Desarrollo económico, vol. 35, No. 138, Buenos Aires, Institute of Economic and Social Development. 
Vapñarsky, C. and N. Gorojovsky (1990), El crecimiento urbano en la Argentina, Buenos Aires, Grupo Editor Latinoamericano.

Vázquez Barquero, A. (2000), "Desarrollo económico local y descentralización: aproximación a un marco conceptual”, Santiago, Chile, Economic Commission for Latin America and the Caribbean (ECLAC).

Wolfe, D. and M. Gertler (2004), "Clusters from the inside and out: local dynamics and global linkages", Urban Studies, vol. 41, No. 5/6, Thousand Oaks, Sage Publications.

Yoguel, G. (2003), "La política científica y tecnológica argentina en las últimas décadas: algunas consideraciones desde la perspectiva del desarrollo de procesos de aprendizaje", Santiago, Chile, unpublished.

(2000), "El aislamiento de las firmas y el rol del ambiente de negocios", Los problemas del entorno de negocios. El desarrollo competitivo de las pymes Argentinas, V. MooriKoenig and G. Yoguel (eds.), Buenos Aires, Editorial, Miño y Dávila.

Yoguel, G. and F. Boscherini (2001), "El desarrollo de las capacidades innovativas de las firmas y el rol del sistema territorial", Desarrollo económico, vol. 41, No. 161, Buenos Aires, Institute of Economic and Social Development.

(1996), "La capacidad innovativa y el fortalecimiento de la competitividad de las firmas: el caso de las pymes exportadoras argentinas", Documento de trabajo, No. 71 (LC/BUE/L.154), Buenos Aires, ECLAC office in Buenos Aires.

Yoguel, G. and M. López (2000), "Sistemas locales de innovación y el desarrollo de la capacidad innovativa de las firmas: las evidencias del cuasi-distrito de Rafaela”, Revista Redes, vol. 7, No. 15, Buenos Aires, Universidad Nacional de Quilmes.

Yoguel, G., M. Novick and D. Milesi (2003), "Entorno productivo y ventajas competitivas: el caso de una trama siderúrgica", Informes de investigación, No. 15, Los Polvorines, Universidad Nacional de General Sarmiento.

Yoguel, G., V. Robert and A. Erbes (2009), "Capacities, innovation and feedbacks in industrial firms in Argentina", Economics of Innovation and New Technology, London, Taylor \& Francis, forthcoming. 